\title{
Overnight Levels of Luteinizing Hormone, Follicle-Stimulating Hormone and Growth Hormone before and during Gonadotropin- Releasing Hormone Analogue Treatment in Short Boys Born Small for Gestational Age
}

\author{
Daniëlle C.M. van der Kaay ${ }^{a, c}$ Frank H. de Jong ${ }^{\text {b }}$ Susan R. Rose ${ }^{g}$ \\ Roelof J.H. Odink ${ }^{d}$ Willie M. Bakker-van Waarde ${ }^{e}$ Eric J. Sulkers ${ }^{f}$ \\ Anita C.S. Hokken-Koelega ${ }^{a, c}$ \\ a Department of Pediatrics, Division of Endocrinology, ${ }^{b}$ Department of Internal Medicine, Erasmus Medical Center, \\ 'Dutch Growth Research Foundation, Rotterdam, dDepartment of Pediatrics, Catharina Hospital, Eindhoven, \\ e Department of Pediatrics, Division of Endocrinology, University Medical Center, Groningen, and fDepartment of \\ Pediatrics, Walcheren Hospital, Vlissingen, The Netherlands; ${ }^{9}$ Department of Pediatrics, Cincinnati Children's \\ Hospital Medical Center and University of Cincinnati, Cincinnati, Ohio, USA
}

\section{Key Words}

Small for gestational age $\cdot$ Luteinizing hormone levels .

Follicle-stimulating hormone levels $\cdot$ Growth hormone

levels · Gonadotropin-releasing hormone analogue treatment

\begin{abstract}
Aims: To evaluate if 3 months of gonadotropin-releasing hormone analogue $(\mathrm{GnRHa})$ treatment results in sufficient suppression of pubertal luteinizing hormone $(\mathrm{LH})$ and follicle-stimulating hormone (FSH) profile patterns in short pubertal small for gestational age (SGA) boys. To compare growth hormone $(\mathrm{GH})$ profiles and fasting insulin-like growth factor (IGF)-I and IGF-binding protein-3 (IGFBP-3) levels after 3 months of GnRHa treatment with those at baseline. Methods: After measurement of baseline overnight profiles and IGF-I and IGFBP-3 levels, 14 short pubertal SGA boys received
\end{abstract}

leuprorelide acetate depots of $3.75 \mathrm{mg}$ subcutaneously, every 4 weeks. Results: At baseline, mean GH levels were comparable with those of controls, whereas IGF-I and IGFBP-3 standard deviation scores (SDS) were significantly lower than zero SDS. After 3 months of GnRHa treatment, all boys showed clinical arrest of puberty. The area under the curve above zero, mean and maximum LH and FSH had significantly decreased to prepubertal levels. Peak LH during the GnRH agonist test, however, indicated insufficient pubertal suppression in $43 \%$ of boys. Overnight GH profile characteristics and IGF-I and IGFBP-3 levels did not significantly change. Conclusions: Puberty was sufficiently suppressed by GnRHa treatment, as shown by the prepubertal LH and FSH profiles. After 3 months of GnRHa treatment, overnight GH profile characteristics had not significantly changed, reflecting that GH levels are comparable for prepubertal and early pubertal boys.

Copyright $\odot 2009$ S. Karger AG, Basel

\section{KARGER}

Fax +41613061234 E-Mail karger@karger.ch www.karger.com (c) 2009 S. Karger AG, Basel

0301-0163/09/0715-0260\$26.00/0

Accessible online at:

www.karger.com/hre
Daniëlle van der Kaay

Dutch Growth Research Foundation

PO Box 23068

$3001 \mathrm{~KB}$ Rotterdam (The Netherlands)

Tel. +31 102251 533, Fax +31 102250 133, E-Mail d.vanderkaay@kindengroei.nl 


\section{Introduction}

Although catch-up growth occurs in most children born small for gestational age (SGA), about $10 \%$ of infants remain short throughout childhood and adulthood $[1,2]$. Persistent changes in the growth hormone (GH)/insulinlike growth factor (IGF)/IGF-binding protein (IGFBP) axis might underlie this failure in catch-up growth [3-7].

In some short SGA children, puberty starts at a relatively early age for their short stature, thereby compromising adult height $[8,9]$. Postponement of puberty with gonadotropin-releasing hormone analogue (GnRHa) treatment was studied in boys with central precocious puberty, and most of these boys reached an adult height in the range of their genetic height potential [10].

In healthy, older prepubertal boys, a very discrete day and night pulsatile secretion pattern of luteinizing hormone (LH) and follicle-stimulating hormone (FSH) is detectable [11-13]. At the onset of puberty (G2), LH and FSH are secreted in a regular pattern during the daytime, with a further amplification during sleep. From early puberty onwards, increasing pulse frequency and pulse amplitude with an obvious night/day rhythm was found [1114].

Data concerning spontaneous overnight $\mathrm{LH}$ and FSH profile patterns during GnRHa treatment are scarce. Therefore, our primary objective was to evaluate if GnRHa treatment results in sufficient suppression of pubertal LH and FSH profile patterns. Admitting children to a hospital in order to perform overnight $\mathrm{LH}$ and FSH profiles is not feasible in routine care. Therefore, all the boys in our study also underwent a GnRH agonist test during the morning after the second overnight profile. In the Netherlands, a consensus-based peak LH level below $3 \mathrm{IU} / \mathrm{l}$ (peak $\mathrm{LH}_{\mathrm{GnRH}}$; 95th percentile of prepubertal peak $\mathrm{LH}$ response) with testosterone levels below $1 \mathrm{nmol} / \mathrm{l}$ (upper limit of prepubertal values) during a GnRH agonist test are used as cutoff levels for sufficient pubertal suppression [15]. Our second objective was to evaluate in how many boys sufficient pubertal suppression is identified by the GnRH agonist test.

A decrease in growth velocity is a well-known phenomenon during GnRHa treatment [16-19]. There are only limited data on spontaneous GH, IGF-I and IGFBP3 levels during GnRHa treatment [20-22]. Notably, no data are available in short pubertal boys born SGA, either before or during GnRHa treatment. Therefore, our third objective was to determine overnight $\mathrm{GH}$ profiles and fasting levels of IGF-I and IGFBP-3, both before and after 3 months of GnRHa treatment.

LH, FSH and GH Levels during GnRHa

Treatment in Short SGA Boys

\section{Subjects and Methods}

Subjects

The study group comprised short boys born SGA who were at the beginning of puberty. They were included in a clinical trial investigating combined treatment with GnRHa and GH. All boys started GH treatment after 3 months of GnRHa treatment. Children who met the following criteria were included: (1) birth length and/or birth weight standard deviation score (SDS) below -2 for gestational age [23], (2) chronological age of 8 years or older at the start of the study, (3) current height SDS below -2.5 or a predicted adult height less than -2.5 SDS (calculated as height at the start of puberty plus $30 \mathrm{~cm}$, according to Dutch references [24]) and (4) early pubertal stage defined as a testicular volume of $4 \mathrm{ml}$ or more, Tanner genital stage 2 or 3 [25] and a GnRH agonist test result with a peak LH of $10 \mathrm{IU} / \mathrm{l}$ or more, indicating central puberty [26]. Children were excluded if they met one of the following criteria: (1) a complicated neonatal period with signs of severe asphyxia (defined as an Apgar score $<3$ after $5 \mathrm{~min}$ ), (2) long-term complications of respiratory ventilation such as bronchopulmonary dysplasia, (3) endocrine (including idiopathic GH deficiency) or metabolic disorders, chromosomal defects, growth failures caused by other disorders (such as emotional deprivation, severe chronic illness or achondroplasia) or syndromes (except for Silver-Russell syndrome) and (4) previous or present medication that could interfere with growth or GH treatment. The study was approved by the Medical Ethics Committee of the participating centers, and written informed consent was obtained from parents or custodians and from subjects if aged 12 years or older.

\section{Study Design}

Overnight LH, FSH and GH profiles were performed in 10 boys, both before and after 3 months of GnRHa treatment (leuprorelide acetate depots of $3.75 \mathrm{mg}$ subcutaneously, every 4 weeks, with an interval of 14 days between the first 2 injections). Children were admitted to the hospital and an indwelling venous catheter was inserted in an antecubital vein. For a period of $12 \mathrm{~h}$ (19.00-7.20 h), blood was taken every $20 \mathrm{~min}$ for determination of serum LH, FSH and GH levels. Children followed their normal eating and sleeping pattern. Sleep during both admissions was recorded by the same investigator (D.vdK.). All children went to bed at $22.30 \mathrm{~h}$, were asleep before $23.30 \mathrm{~h}$ and woke up around $7.00 \mathrm{~h}$ the next morning. The time awake was comparable between both admissions. The next morning, a fasting blood sample was taken for measurement of IGF-I and IGFBP-3 levels.

Height was measured using a Harpenden stadiometer and expressed as SDS for calendar age [24]. The same investigator (D. vdK.) assessed pubertal stage according to Tanner during both visits, using an orchidometer [25]. Bone age was assessed by one investigator (D.vdK.), using the segmented Greulich and Pyle reference [27]. Fat mass for height at baseline was measured by dualenergy X-ray absorptiometry [28].

The inhibition of gonadotropin secretion was checked the morning after the second overnight profile by a $\mathrm{GnRH}$ agonist test, as follows: $0.5 \mathrm{mg}(0.5 \mathrm{ml})$ of leuprorelide acetate was injected subcutaneously, and after $3 \mathrm{~h}$, a blood sample was taken for determination of LH, FSH and testosterone levels [29, 30]. In the 4 boys in whom overnight profiles were not performed, fasting IGF-I and IGFBP-3 levels and a GnRH agonist test were performed during the second visit, after 3 months of GnRHa treat- 
Table 1. Clinical characteristics before the start of GnRHa treatment

\begin{tabular}{ll}
\hline Number of boys & 14 \\
Gestational age, weeks & $39.0(37.4-40.0)$ \\
Birth weight SDS & $-1.9(-2.2$ to -1.6$)$ \\
Birth length SDS & $-2.4(-2.8$ to -2.1$)$ \\
\hline At start of GnRHa treatment & \\
Genital stage 2, n & 12 \\
Genital stage 3, n & 2 \\
Age, years & $12.7(12.2-12.9)$ \\
Bone age, years & $12.1(11.2-12.6)$ \\
Height SDS & $-2.5(-3.4$ to -2.2$)$ \\
Weight SDS & $-2.7(-3.4$ to -1.3$)$ \\
Fat mass SDS & $-0.5(-1.4$ to -0.08$)$ \\
\hline
\end{tabular}

Data are expressed as medians (interquartile range in parentheses).

ment. We compared our overnight GH profile results with those found by Rose et al. [31], who performed overnight GH profiles in healthy boys with normal stature and similar pubertal stage.

\section{Hormone Assays}

Overnight LH and FSH levels were measured by chemiluminescence-based immunometric methods (Immulite 2000, Diagnostic Products Corporation, Los Angeles, Calif., USA) using WHO preparations $80 / 552$ and 78/549 as standards. Detection limits for both assays were $0.1 \mathrm{IU} / \mathrm{l}$, and values below $0.1 \mathrm{IU} / 1$ were assigned the value $0.1 \mathrm{IU} / \mathrm{l}$. Intra- and interassay coefficients of variation (CVs) were below 4 and 7\%, respectively, for LH and below 3 and 6\%, respectively, for FSH. Testosterone levels were measured using a coated-tube radioimmunoassay obtained from $\mathrm{Di}$ agnostic Products Corporation. The detection limit for this assay is $0.1 \mathrm{nmol} / \mathrm{l}$. Intra- and interassay CVs were below 6 and $8 \%$, respectively.

Overnight GH levels were measured by an immunometric assay (Immulite 2000) with a lower detection limit of $0.13 \mathrm{mU} / \mathrm{l}$. Values lower than $0.13 \mathrm{mU} / \mathrm{l}$ were assigned the value $0.13 \mathrm{mU} / \mathrm{l}$. The results of low, medium and high standards [mean \pm intraassay standard deviation (SD) and \pm interassay SD, respectively] were $6.8 \pm 0.23$ and $\pm 0.44,14.0 \pm 0.47$ and \pm 0.75 , and $44 \pm$ 1.87 and $\pm 2.94 \mathrm{mU} / \mathrm{l}$, respectively. Intra- and interassay $\mathrm{CVs}$ were, respectively, 3.5 and $6.5 \%$ at a level of $6.8 \mathrm{mU} / \mathrm{l}, 3.4$ and $5.5 \%$ at a level of $14.0 \mathrm{mU} / \mathrm{l}$ and 4.2 and $6.6 \%$ at a level of $44 \mathrm{mU} / \mathrm{l}$. Based on standard samples, our assay was comparable with the assay used by Kamp et al. [20], who measured GH levels by polyclonal radioimmunoassay with a detection limit of $0.5 \mu \mathrm{g} / \mathrm{l}$. Their results (mean \pm SD) of low, medium and high standards were 1.1 $\pm 0.1,3.6 \pm 0.4$ and $16.9 \pm 2.0 \mu \mathrm{g} / \mathrm{l}$, respectively. Intra- and interassay CVs were, respectively, 9.1 and $18.7 \%$ at a level of $1.2 \mu \mathrm{g} / \mathrm{l}$, 3.7 and $16.6 \%$ at a level of $5.1 \mu \mathrm{g} / \mathrm{l}$ and 3.1 and $9.0 \%$ at a level of $18.5 \mu \mathrm{g} / \mathrm{l}$. A conversion factor of 2.6 was used to transform data from micrograms per liter to milliunits per liter [32].

Serum IGF-I and IGFBP-3 levels were measured in one laboratory using a specific radioimmunoassay [33]. Serum levels were expressed as SDS to adjust for age and sex [34]. The intra- and interassay CVs were 4 and 6\%, respectively.

Reported LH Profiles for Prepubertal Boys

Prepubertal boys with a testicular volume of $1-2 \mathrm{ml}$ have a very discrete nighttime pulsatile pattern of gonadotropin secretion with mean $( \pm$ SEM) LH levels of $0.27 \pm 0.15 \mathrm{IU} / \mathrm{l}$ and maximum LH levels of $1.06 \pm 0.24 \mathrm{IU} / \mathrm{l}$. Mean and maximum LH levels increased to $1.34 \pm 0.42$ and $3.70 \pm 1.21 \mathrm{IU} / \mathrm{l}$, respectively, in prepubertal boys with a testicular volume of $3 \mathrm{ml}$ [12].

\section{Calculations}

The area under the curve above zero $\left(\mathrm{AUC}_{0}\right)$ of $\mathrm{LH}$ and FSH profile patterns was calculated by the trapezoidal method. Overnight $\mathrm{GH}$ profiles were analyzed using the Pulsar program [33, 35].

\section{Statistics}

Because of a non-Gaussian-shaped distribution, data were expressed as medians (interquartile range in parentheses). The Mann-Whitney test was used for differences between groups. The Wilcoxon signed rank test was used to determine differences between points in time within groups. SDS were compared with zero SDS using $\chi^{2}$ tests. To analyze night-to-night variation, correlation coefficients were calculated between individual time points for an individual patient. The calculated coefficients were analyzed using $\chi^{2}$ tests. Spearman's correlation coefficient was used for correlations. A p value $<0.05$ was considered significant. Analyses were performed using the computer statistical package SPSS (version 11) for Windows.

\section{Results}

\section{Clinical Characteristics}

Table 1 shows the clinical data of all subjects. After 3 months of GnRHa treatment, none of the boys showed clinical progression of puberty and 2 boys showed clinical regression of puberty.

\section{Overnight LH and FSH Profiles}

Baseline. Characteristics of baseline overnight LH and FSH profiles are shown in table 2.

After 3 Months of GnRHa Treatment. Characteristics of overnight $\mathrm{LH}$ and $\mathrm{FSH}$ profiles after 3 months of GnRHa treatment are shown in table $2 . \mathrm{AUC}_{0}$, mean and maximum LH and FSH levels had significantly decreased to very low levels. Mean LH levels were $0.41 \mathrm{IU} / \mathrm{l}$ and maximum LH levels were $0.72 \mathrm{IU} / \mathrm{l}$, whereas mean FSH levels were $0.21 \mathrm{IU} / \mathrm{l}$ and maximum FSH levels were 0.38 IU/l. Thus, none of the boys had a pubertal pulsatile pattern (fig. 1, 2).

GnRH Agonist Test. After 3 months of GnRHa treatment, peak $\mathrm{LH}_{\mathrm{GnRH}}$ was below $3 \mathrm{IU} / \mathrm{l}$, with testosterone levels below $1 \mathrm{nmol} / \mathrm{l}$ in 8 out of 14 boys. Peak $\mathrm{LH}_{\mathrm{GnRH}}$ 


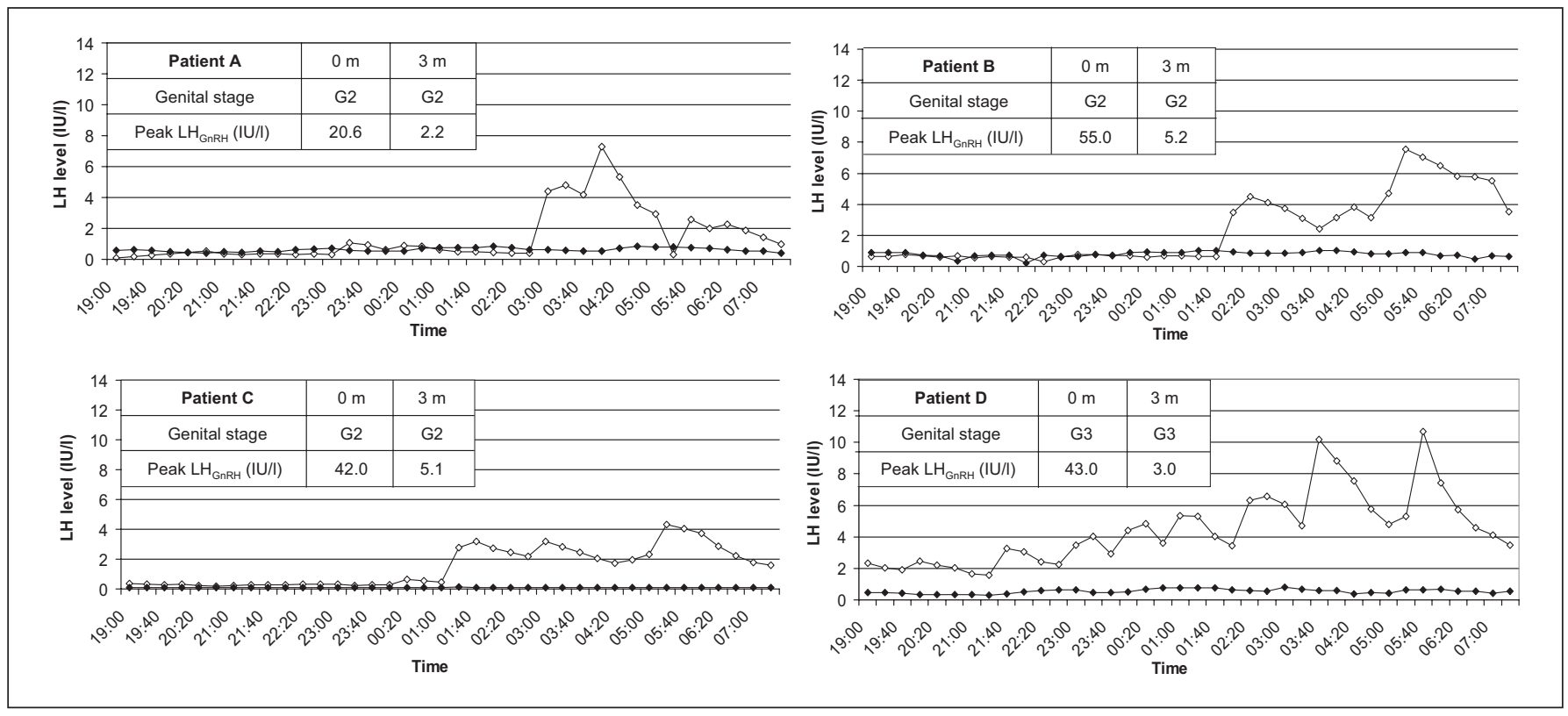

Fig. 1. Representative examples of individual overnight LH profiles in 4 boys, performed at baseline $(\diamond)$ and after 3 months of GnRHa treatment $(\checkmark)$. Subjects A, B and C were genital stage 2, while subject $\mathrm{D}$ was genital stage 3 . The results of the GnRH agonist test performed after 3 months of GnRHa treatment are shown in the insets. $\mathrm{m}=$ Months. varied between 3.3 and $5.2 \mathrm{IU} / \mathrm{l}$ in 6 boys (43\%). Testosterone levels were below $1 \mathrm{nmol} / \mathrm{l}$ in all 6 boys, and none of these boys showed clinical progression. No significant differences in LH and FSH profiles were found between boys with a peak $\mathrm{LH}_{\mathrm{GnRH}}$ above or below 3 IU/l. Testosterone levels had significantly decreased from 6.5 (1.39.9) $\mathrm{nmol} / \mathrm{l}$ to $0.25(0.10-0.53) \mathrm{nmol} / \mathrm{l}(\mathrm{p}=0.001)$ after 3 months of GnRHa treatment. No significant differences in testosterone levels were found between boys with a peak $\mathrm{LH}_{\mathrm{GnRH}}$ above or below $3 \mathrm{IU} / \mathrm{l}$.

Correlations between LH Profiles and the GnRH Agonist Test. At baseline, mean LH levels during the LH profile correlated positively with testosterone levels during the $\mathrm{GnRH}$ agonist test $(\mathrm{r}=0.67, \mathrm{p}=0.03)$. Maximum LH levels during the $\mathrm{LH}$ profile correlated positively with peak $\mathrm{LH}_{\mathrm{GnRH}}$ $(\mathrm{r}=0.69, \mathrm{p}=0.03)$. After 3 months of GnRHa treatment, no correlations were found between characteristics of the $\mathrm{LH}$ profiles and peak LH or testosterone levels during the GnRH agonist test. Peak $\mathrm{LH}_{\mathrm{GnRH}}$ and peak $\mathrm{FSH}_{\mathrm{GnRH}}$ at baseline correlated respectively with peak $\mathrm{LH}_{\mathrm{GnRH}}$ and peak $\mathrm{FSH}_{\mathrm{GnRH}}$ after 3 months of GnRHa treatment $(\mathrm{r}=$ $0.73, \mathrm{p}=0.003$ and $\mathrm{r}=0.70, \mathrm{p}=0.006$, respectively).

Overnight GH Profiles and IGF-I and IGFBP-3 Levels

Baseline. Characteristics of the overnight GH profiles and IGF-I and IGFBP-3 levels at baseline are listed in ta-
Table 2. Characteristics of overnight LH and FSH profiles, at baseline and after 3 months of GnRHa treatment

\begin{tabular}{lccc}
\hline & Baseline & 3 months & p value \\
\hline Overnight LH profiles & & & \\
AUC $_{0}$ LH, IU/l $\times 12 \mathrm{~h}$ & $36.0(18.1-52.1)$ & $5.2(3.7-8.3)$ & 0.005 \\
Mean LH, IU/l & $2.8(1.4-4.1)$ & $0.41(0.29-0.66)$ & 0.005 \\
Maximum LH, IU/l & $7.3(4.3-9.7)$ & $0.72(0.43-0.92)$ & 0.005 \\
\hline Overnight FSH profiles & & & \\
AUC 0 FSH, IU/l $\times 12$ h & $21.0(11.3-63.7)$ & $2.7(1.5-5.3)$ & 0.005 \\
Mean FSH, IU/l & $1.7(0.89-5.0)$ & $0.21(0.12-0.42)$ & 0.005 \\
Maximum FSH, IU/l & $4.0(1.6-6.3)$ & $0.38(0.22-0.93)$ & 0.005 \\
\hline GnRH agonist test & & & \\
Peak LH, IU/l & $32.4(14.1-43.1)$ & $2.8(2.1-4.0)$ & 0.001 \\
Peak FSH, IU/l & $7.2(4.3-11.8)$ & $0.65(0.40-1.1)$ & 0.001 \\
Testosterone, nmol/l & $6.5(1.3-9.9)$ & $0.25(0.10-0.53)$ & 0.001 \\
\hline
\end{tabular}

Data are expressed as medians (interquartile range in parentheses). Reported mean prepubertal values for mean and maximum LH levels are $0.27-1.3$ and 1.1-3.7 IU/l, respectively. $p$ values are calculated compared to baseline.

ble 3. Mean GH levels in boys with genital stage 2 were comparable with mean GH levels found in boys with normal stature and similar genital stage. Since only 2 boys had genital stage 3 , a comparison with boys with normal stature and similar pubertal stage was not feasible. IGF-I 


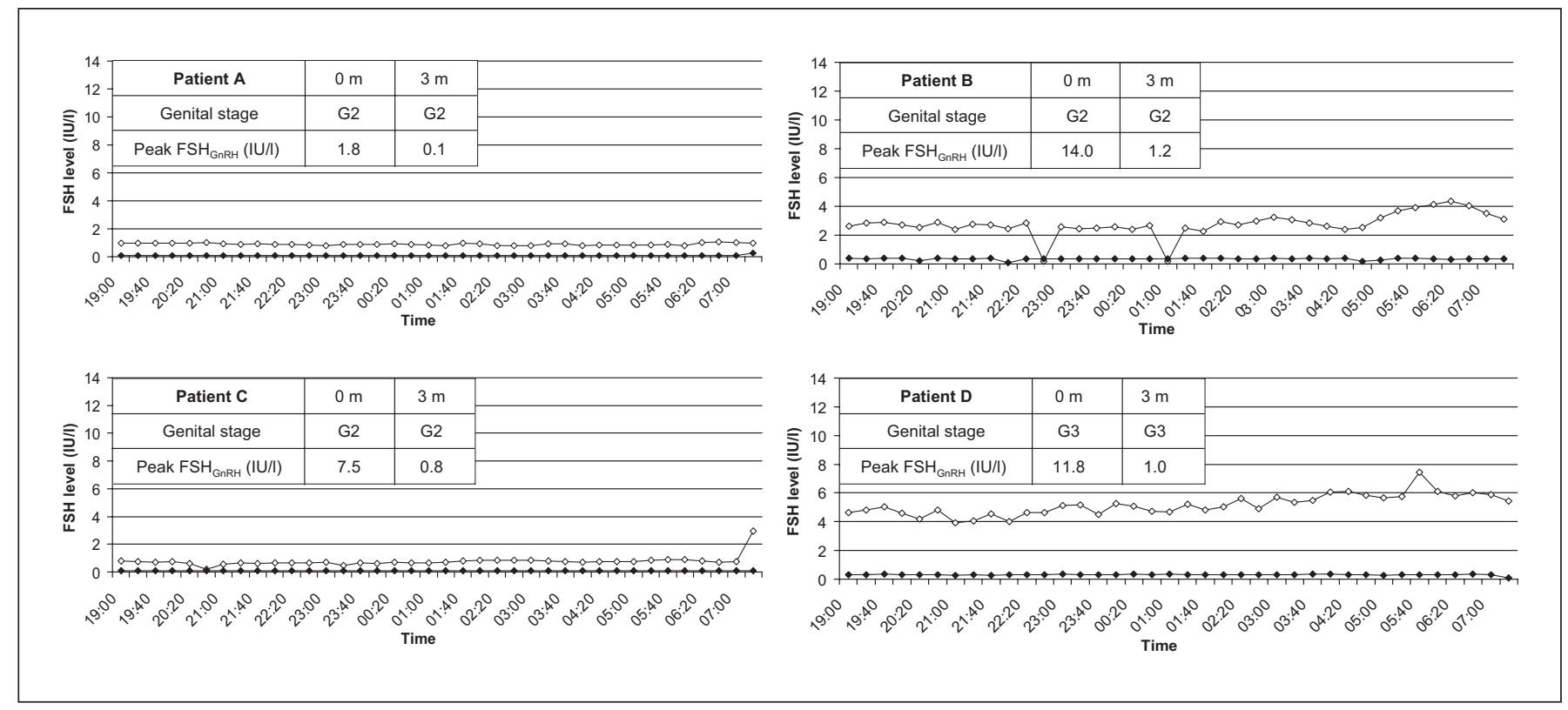

Fig. 2. Representative examples of individual overnight FSH profiles in the same 4 boys as shown in figure 1, performed at baseline $(\diamond)$ and after 3 months of GnRHa treatment $(\diamond)$. Subjects A, B and

$\mathrm{C}$ were genital stage 2 , while subject $\mathrm{D}$ was genital stage 3 . The results of the GnRH agonist test performed after 3 months of GnRHa treatment are shown in the insets. $\mathrm{m}=$ Months.

Table 3. Characteristics of overnight GH, IGF-I and IGFPB-3 levels, at baseline and after 3 months of GnRHa treatment

\begin{tabular}{llll}
\hline & Baseline & 3 months & $\begin{array}{l}\mathrm{p} \\
\text { value }\end{array}$ \\
\hline AUC $_{0}, \mathrm{mU} / \mathrm{l} \times 12 \mathrm{~h}$ & $135(92.1-263)$ & $130(70.0-238)$ & 0.6 \\
Mean GH, mU/l & $10.8(7.3-20.8)$ & $10.4(5.6-18.8)$ & 0.6 \\
Maximum GH, mU/l & $46.2(32.8-137.8)$ & $55.3(30.9-89.7)$ & 0.4 \\
Pulse amplitude, mU/l & $16.4(13.7-32.5)$ & $22.8(11.6-32.7)$ & 0.4 \\
Number of GH peaks $>10$ & & & \\
$\quad$ mU $/ 1$ & $3.5(2.8-5.0)$ & $4.0(3.0-4.0)$ & 1.0 \\
IGF-I SDS & $-0.8(-1.5 \text { to }-0.04)^{\mathrm{a}}$ & $-0.9(-1.4 \text { to }-0.2)^{\mathrm{a}}$ & 0.6 \\
IGFBP-3 SDS & $-1.0(-1.5 \text { to }-0.6)^{\mathrm{b}}$ & $-1.2(-1.7 \text { to }-0.7)^{\mathrm{b}}$ & 0.1 \\
\hline
\end{tabular}

Data are expressed as medians (interquartile range in parentheses). $\mathrm{p}$ values calculated comparing data at 3 months to those at baseline.

${ }^{\mathrm{a}} \mathrm{p} \leq 0.05$ compared to zero SDS; ${ }^{\mathrm{b}} \mathrm{p} \leq 0.001$ compared to zero SDS.

and IGFBP-3 levels were significantly lower than zero SDS ( $\mathrm{p}=0.03$ and $\mathrm{p}=0.001$, respectively).

After 3 Months of GnRHa Treatment. Characteristics of overnight GH profiles, IGF-I and IGFBP-3 levels after 3 months of GnRHa treatment are listed in table 3. No significant differences were found between GH profile characteristics at baseline and after 3 months of GnRHa treatment. Mean GH levels remained comparable with those found in controls. Figure 3 shows that there was a

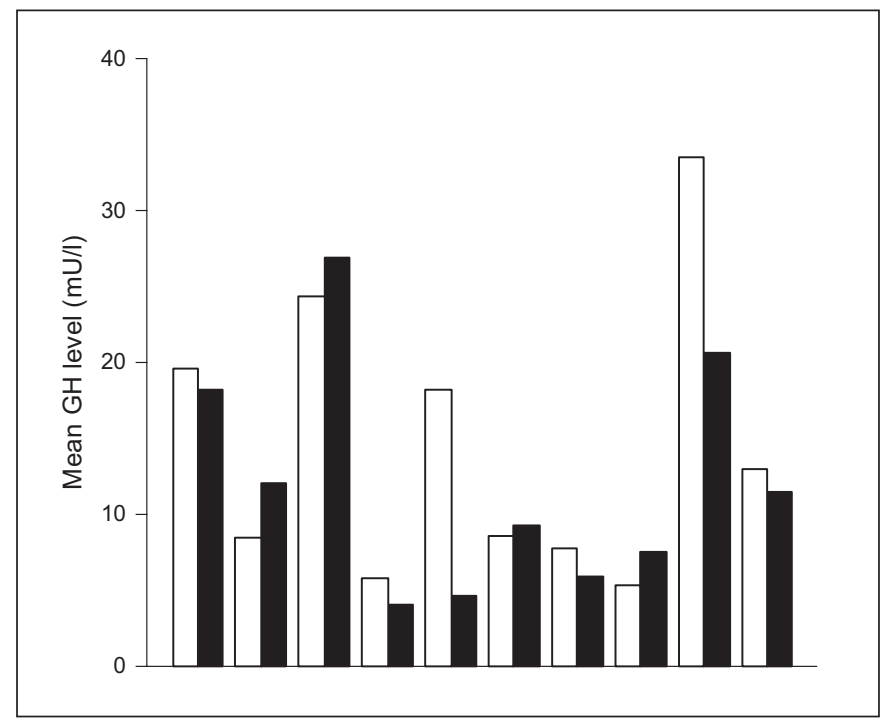

Fig. 3. Mean GH levels for each subject during overnight GH profiles, at baseline (open bars) and after 3 months of GnRHa treatment (solid bars).

wide interindividual variation in mean serum GH levels, both at baseline and after 3 months of GnRHa treatment. IGF-I and IGFBP-3 levels did not significantly change and SDS values remained significantly lower than zero 
SDS ( $p=0.03$ and $p<0.001$, respectively). In all boys, there was a significant correlation between the timing of GH peaks at baseline and after 3 months of GnRHa treatment $(\mathrm{r}=0.4, \mathrm{p}=0.01)$.

Correlations between GH Profiles, Clinical Characteristics and the GnRH Agonist Test. Neither at baseline nor after 3 months of GnRHa treatment were correlations found between characteristics of the overnight GH profiles and age, height SDS, peak $\mathrm{LH}_{\mathrm{GnRH}}$, bone age (at baseline) or fat mass SDS (at baseline).

Correlations between GH Profiles and IGF-Iand IGFBP3 Levels. At baseline, mean GH levels correlated significantly with IGF-I SDS ( $r=0.72, p=0.02)$. After 3 months of GnRHa treatment, mean GH levels correlated significantly with IGF-I SDS $(\mathrm{r}=0.76, \mathrm{p}=0.01)$ and IGFBP-3 $\operatorname{SDS}(\mathrm{r}=0.64, \mathrm{p}=0.048)$. Maximum GH levels correlated significantly with IGF-I SDS $(r=0.69, \mathrm{p}=0.03)$.

\section{Discussion}

In the present study, LH and FSH levels had significantly decreased to prepubertal levels in all boys, showing that treatment with leuprorelide acetate depots of 3.75 mg subcutaneously every 4 weeks resulted in an adequate suppression of puberty. The GnRH agonist test performed after 3 months of GnRHa treatment falsely indicated insufficient pubertal suppression in $43 \%$ of the boys. No significant changes in overnight $\mathrm{GH}$ profile characteristics and IGF-I and IGFBP-3 SDS were found after 3 months of GnRHa treatment, compared to baseline.

\section{Overnight LH and FSH Profiles}

After 3 months of GnRHa treatment, all boys had clinical arrest of puberty and 2 boys had clinical regression of puberty. $\mathrm{AUC}_{0}$, mean and maximum $\mathrm{LH}$ and $\mathrm{FSH}$ levels had significantly decreased to very low levels. The pattern of LH and FSH profiles after 3 months of GnRHa treatment in short boys born SGA was similar to prepubertal profiles found in healthy boys [12].

Overnight $\mathrm{LH}$ and $\mathrm{FSH}$ profiles were performed for research purposes since admitting children to a hospital in order to perform overnight profiles is not suitable for routine clinical care. After 3 months of GnRHa treatment, peak $\mathrm{LH}_{\mathrm{GnRH}}$ was above the cutoff level of $3 \mathrm{IU} / \mathrm{l}$ in $43 \%$ of the boys [15]. Notably, all boys had prepubertal testosterone levels (below $1 \mathrm{nmol} / \mathrm{l}$ ). Furthermore, no significant differences in $\mathrm{LH}$ and $\mathrm{FSH}$ profiles were found between boys with a peak $\mathrm{LH}_{\mathrm{GnRH}}$ above or below $3 \mathrm{IU} / \mathrm{l}$. Our findings are in agreement with the only comparable study, performed in 6 children ( 2 boys) with central precocious puberty [36]. In this study, children who had clinically well suppressed puberty had LH levels similar to prepubertal children.

Peak $\mathrm{LH}_{\mathrm{GnRH}}$ was known before $\mathrm{LH}$ levels during the overnight profiles were available. The schedule of leuprorelide acetate depot injections was changed to every 3 weeks instead of every 4 weeks in boys with a peak $\mathrm{LH}_{\mathrm{GnRH}}$ above $3 \mathrm{IU} / \mathrm{l}$, according to Dutch consensus guidelines. This adjustment seemed to be unnecessary once we received the results of the overnight LH profiles.

Although we found prepubertal LH profiles in all boys after 3 months of GnRHa treatment, LH and FSH profiles were determined in a rather small group. In order to determine which peak $\mathrm{LH}_{\mathrm{GnRH}}$ cutoff level indicates sufficient pubertal suppression, we recommend future research in a larger study group, including boys and girls with different pubertal stages and with sufficient and insufficient pubertal suppression according to their LH profiles.

Overnight GH Profiles, IGF-I and IGFBP-3 Levels

To our knowledge, this is the first study describing baseline GH profiles in short pubertal boys born SGA. We found normal mean GH levels, compared to boys with normal stature and similar pubertal stage [20]. Overnight GH profiles have been performed in prepubertal short SGA children with conflicting results. Some authors reported significantly lower levels in short children born SGA, compared to healthy children born appropriate for gestational age $[3,4]$, whereas others found comparable mean GH levels [37]. The wide variability in and overlap between GH secretion seen in SGA cohorts and control populations are consistent phenomena $[3,4$, $20,37]$. Within the heterogeneous SGA population, this probably reflects a continuum in $\mathrm{GH}$ secretion, ranging from $\mathrm{GH}$ deficiency to normal GH secretion. Alterations in the GH/IGF/IGFBP pathway and genetic variations found in genes involved in this pathway $[38,39]$ might in part explain this continuum.

Baseline IGF-I and IGFBP-3 SDS were significantly lower than zero SDS, which is in line with previous studies describing low IGF-I and IGFBP-3 levels throughout childhood in subjects born SGA $[6,40,41]$. IGF-I SDS was significantly correlated with mean GH levels, both at baseline and after 3 months of GnRHa treatment, and IGFBP-3 SDS was significantly correlated with mean GH levels after 3 months of GnRHa treatment. IGF-I and IGFBP-3 levels were found to reflect GH secretion in healthy children [42]. Our study shows that this reflection is also applicable for short boys born SGA. 
After 3 months of GnRHa treatment, we found no significant changes in $\mathrm{AUC}_{0}$, mean and maximum $\mathrm{GH}$ levels compared to baseline. Likewise, IGF-I and IGFBP-3 levels had not significantly changed. Rose et al. [31] showed that mean GH levels in healthy boys with testicular volumes between 5 and $10 \mathrm{ml}$ remained near prepubertal levels, whereas a significant increase in spontaneous GH and IGF-I levels was found when Tanner stage 3 was reached. In our study, all boys in whom overnight GH profiles were performed had testicular volumes between 4 and $8 \mathrm{ml}$. Thus, this could well explain why we did not find significant changes in GH and IGF-I levels after 3 months of GnRHa treatment.

We found a significant trend in the timing of $\mathrm{GH}$ peaks within the same individual. The reproducibility of measurements of overnight $\mathrm{GH}$ secretion was reported to be superior to that of provocative tests [32]. The intraindividual reproducibility was found to be less profound [43]. Our results indicate the existence of an intrinsic rhythm regulating endogenous $\mathrm{GH}$ secretion in individual subjects.

In conclusion, treatment with leuprorelide acetate depots of $3.75 \mathrm{mg}$ every 4 weeks results in an effective inhibition of central puberty, as shown by prepubertal overnight LH and FSH secretion patterns and clinical signs of pubertal arrest. The GnRH agonist test falsely indicated insufficient pubertal suppression in almost half of the boys, resulting in unnecessary adjustments in the fre- quency of depot injections. Low IGF-I and IGFBP-3 levels were found at the start of puberty, although mean GH levels were normal for pubertal stage. Parameters of the overnight GH profile did not significantly change after 3 months of GnRHa treatment, consistent with GH levels being comparable for prepubertal and early pubertal boys.

\section{Acknowledgements}

We thank all children and their parents for participating in this study. We very much appreciate the technical assistance of Mrs. Jolanda van Houten, research nurse. The participating physicians were: J.C. Mulder, Rijnstate Hospital, Arnhem, the Netherlands; J.J.J. Waelkens, Catharina Hospital, Eindhoven, the Netherlands; B. Bakker, Leiden University Medical Center, Leiden, the Netherlands; C. Noordam, Radboud University Medical Center Nijmegen, Nijmegen, the Netherlands; C. Westerlaken, Canisius Wilhelmina Hospital, Nijmegen, the Netherlands; E.J. Schroor, Isala Clinics, Zwolle, the Netherlands, and J.P.C.M. van der Hulst, Zaans Medical Center, Zaandam, the Netherlands. We would like to thank Dr. W.H. Hackeng (PhD) for his GH assays. We are thankful for the assistance of Dr. D. Mul during assessment of bone age. We thank Dr. M. de Ridder, statistician, for her assistance during statistical analyses. We are grateful for the support of the nurses working on the Children's Ward, Sophia Children's Hospital. We appreciate the financial support of the Vereniging Trustfonds Erasmus Universiteit Rotterdam for conference visits. We acknowledge the investigator-initiated research grant provided by Pfizer Farma B.V., the Netherlands.

\section{References}

1 Albertsson-Wikland K, Karlberg J: Natural growth in children born small for gestational age with and without catch-up growth. Acta Paediatr Suppl 1994;399:64-70, discussion 71.

-2 Hokken-Koelega AC, De Ridder MA, Lemmen RJ, Den Hartog H, De Muinck KeizerSchrama SM, Drop SL: Children born small for gestational age: do they catch up? Pediatr Res 1995;38:267-271.

- 3 Boguszewski M, Rosberg S, AlbertssonWikland K: Spontaneous 24-hour growth hormone profiles in prepubertal small for gestational age children. J Clin Endocrinol Metab 1995;80:2599-2606.

$\checkmark 4$ de Waal WJ, Hokken-Koelega AC, Stijnen T, de Muinck Keizer-Schrama SM, Drop SL: Endogenous and stimulated GH secretion, urinary GH excretion, and plasma IGF-I and IGF-II levels in prepubertal children with short stature after intrauterine growth retardation. The Dutch Working Group on Growth Hormone. Clin Endocrinol (Oxf) 1994;41:621-630.
5 Sas T, de Waal W, Mulder P, Houdijk M, Jansen M, Reeser M, Hokken-Koelega A: Growth hormone treatment in children with short stature born small for gestational age: 5-year results of a randomized, double-blind, doseresponse trial. JClin Endocrinol Metab 1999; 84:3064-3070.

-6 Verkauskiene R, Jaquet D, Deghmoun S, Chevenne D, Czernichow P, Levy-Marchal $\mathrm{C}$ : Smallness for gestational age is associated with persistent change in insulin-like growth factor I (IGF-I) and the ratio of IGF-I/IGFbinding protein-3 in adulthood. J Clin Endocrinol Metab 2005;90:5672-5676.

7 Stanhope R, Ackland F, Hamill G, Clayton J, Jones J, Preece MA: Physiological growth hormone secretion and response to growth hormone treatment in children with short stature and intrauterine growth retardation. Acta Paediatr Scand Suppl 1989;349:47-52, discussion 53-54.

8 Hokken-Koelega AC: Timing of puberty and fetal growth. Best Pract Res Clin Endocrinol Metab 2002;16:65-71.
-9 Boonstra V, van Pareren Y, Mulder P, Hokken-Koelega A: Puberty in growth hormonetreated children born small for gestational age (SGA). J Clin Endocrinol Metab 2003;88: 5753-5758.

10 Mul D, Bertelloni S, Carel JC, Saggese G, Chaussain JL, Oostdijk W: Effect of gonadotropin-releasing hormone agonist treatment in boys with central precocious puberty: final height results. Horm Res 2002;58:1-7.

-11 Dunkel L, Alfthan H, Stenman UH, Selstam G, Rosberg S, Albertsson-Wikland K: Developmental changes in 24-hour profiles of luteinizing hormone and follicle-stimulating hormone from prepuberty to midstages of puberty in boys. J Clin Endocrinol Metab 1992;74:890-897.

12 Albertsson-Wikland K, Rosberg S, Lannering B, Dunkel L, Selstam G, Norjavaara E: Twenty-four-hour profiles of luteinizing hormone, follicle-stimulating hormone, testosterone, and estradiol levels: a semilongitudinal study throughout puberty in healthy boys. J Clin Endocrinol Metab 1997;82:541-549. 
$\checkmark 13$ Wennink JM, Delemarre-van de Waal HA, Schoemaker R, Schoemaker H, Schoemaker J: Luteinizing hormone and follicle stimulating hormone secretion patterns in boys throughout puberty measured using highly sensitive immunoradiometric assays. Clin Endocrinol (Oxf) 1989;31:551-564.

-14 Oerter KE, Uriarte MM, Rose SR, Barnes KM, Cutler GB Jr: Gonadotropin secretory dynamics during puberty in normal girls and boys. J Clin Endocrinol Metab 1990;71: 1251-1258.

15 Roger M, Lahlou N, Lindner D, Chaussain JL: Gonadotropin-releasing hormone testing in pediatrics; in Ranke MD (ed): Functional Endocrinologic Diagnostics in Children and Adolescents. Mannheim, J\&J Verlag, 1992, pp 229-247.

16 Tato L, Saggese G, Cavallo L, Antoniazzi F, Corrias A, Pasquino AM, Cisternino M: Use of combined Gn-RH agonist and hGH therapy for better attaining the goals in precocious puberty treatment. Horm Res 1995; 44(suppl 3):49-54.

- 17 Saggese G, Bertelloni S, Baroncelli GI, Di Nero G, Battini R: Growth velocity and serum aminoterminal propeptide of type III procollagen in precocious puberty during gonadotropin-releasing hormone analogue treatment. Acta Paediatr 1993;82:261-266.

$\checkmark 18$ Walvoord EC, Pescovitz OH: Combined use of growth hormone and gonadotropin-releasing hormone analogues in precocious puberty: theoretic and practical considerations. Pediatrics 1999;104:1010-1014.

-19 Carel JC, Hay F, Coutant R, Rodrigue D, Chaussain JL: Gonadotropin-releasing hormone agonist treatment of girls with constitutional short stature and normal pubertal development. J Clin Endocrinol Metab 1996; 81:3318-3322.

20 Kamp GA, Manasco PK, Barnes KM, Jones J, Rose SR, Hill SC, Cutler GB Jr: Low growth hormone levels are related to increased body mass index and do not reflect impaired growth in luteinizing hormone-releasing hormone agonist-treated children with precocious puberty. J Clin Endocrinol Metab 1991;72:301-307.

-21 DiMartino-Nardi J, Wu R, Fishman K, Saenger P: The effect of long-acting analog of luteinizing hormone-releasing hormone on growth hormone secretory dynamics in children with precocious puberty. J Clin Endocrinol Metab 1991;73:902-906.

$\checkmark 22$ Stanhope R, Pringle PJ, Brook CG: Growth, growth hormone and sex steroid secretion in girls with central precocious puberty treated with a gonadotrophin releasing hormone (GnRH) analogue. Acta Paediatr Scand 1988;77:525-530.
23 Usher R, McLean F: Intrauterine growth of live-born Caucasian infants at sea level: standards obtained from measurements in 7 dimensions of infants born between 25 and 44 weeks of gestation. J Pediatr 1969;74:901910.

-24 Fredriks AM, van Buuren S, Burgmeijer RJ, Meulmeester JF, Beuker RJ, Brugman E, Roede MJ, Verloove-Vanhorick SP, Wit JM: Continuing positive secular growth change in The Netherlands 1955-1997. Pediatr Res 2000;47:316-323.

25 Tanner JM, Whitehouse RH: Clinical longitudinal standards for height, weight, height velocity, weight velocity, and stages of puberty. Arch Dis Child 1976;51:170-179.

26 Cavallo A, Zhou XH: LHRH test in the assessment of puberty in normal children. Horm Res 1994;41:10-15.

27 Pyle SI, Waterhouse AM, Greulich WW: Attributes of the radiographic standard of reference for the National Health Examination Survey. Am J Phys Anthropol 1971;35:331337.

28 Boot AM, Bouquet J, de Ridder MA, Krenning EP, de Muinck Keizer-Schrama SM: Determinants of body composition measured by dual-energy x-ray absorptiometry in Dutch children and adolescents. Am J Clin Nutr 1997;66:232-238.

29 Mul D, de Muinck Keizer-Schrama SM, Oostdijk W, Drop SL: Auxological and biochemical evaluation of pubertal suppression with the GnRH agonist leuprolide acetate in early and precocious puberty. Horm Res 1999;51:270-276.

30 Ibanez L, Potau N, Zampolli M, Virdis R, Gussinye M, Carrascosa A, Saenger P, Vicens-Calvet E: Use of leuprolide acetate response patterns in the early diagnosis of pubertal disorders: comparison with the gonadotropin-releasing hormone test. J Clin Endocrinol Metab 1994;78:30-35.

31 Rose SR, Municchi G, Barnes KM, Kamp GA, Uriarte MM, Ross JL, Cassorla F, Cutler GB Jr: Spontaneous growth hormone secretion increases during puberty in normal girls and boys. J Clin Endocrinol Metab 1991;73: 428-435.

32 Morsky P, Tiikkainen U, Ruokonen A, Markkanen $\mathrm{H}$ : Problematic determination of serum growth hormone: experience from external quality assurance surveys 1998-2003. Scand J Clin Lab Invest 2005;65:377-386.

33 Hokken-Koelega AC, Hackeng WH, Stijnen T, Wit JM, de Muinck Keizer-Schrama SM, Drop SL: Twenty-four-hour plasma growth hormone $(\mathrm{GH})$ profiles, urinary GH excretion, and plasma insulin-like growth factorand -II levels in prepubertal children with chronic renal insufficiency and severe growth retardation. J Clin Endocrinol Metab 1990;71:688-695.
34 Rikken B, van Doorn J, Ringeling A, Van den Brande JL, Massa G, Wit JM: Plasma levels of insulin-like growth factor (IGF)-I, IGF-II and IGF-binding protein-3 in the evaluation of childhood growth hormone deficiency. Horm Res 1998;50:166-176.

35 Merriam GR, Wachter KW: Algorithms for the study of episodic hormone secretion. Am J Physiol 1982;243:E310-E318.

36 Cook JS, Doty KL, Conn PM, Hansen JR: Assessment of depot leuprolide acetate doseadequacy for central precocious puberty. J Clin Endocrinol Metab 1992;74:1206-1209.

37 Volkl TM, Schwobel K, Simm D, Beier C, Rohrer TR, Dorr HG: Spontaneous growth hormone secretion and IGF1:IGFBP3 molar ratios in children born small for gestational age (SGA). Growth Horm IGF Res 2004;14: 455-461.

38 Boonstra VH, Arends NJ, Stijnen T, Blum WF, Akkerman O, Hokken-Koelega AC: Food intake of children with short stature born small for gestational age before and during a randomized GH trial. Horm Res 2006;65:23-30.

39 Carrascosa A, Esteban C, Espadero R, Fernandez-Cancio M, Andaluz P, Clemente M, Audi L, Wollmann H, Fryklund L, Parodi L: The $\mathrm{d} 3 /$ fl-growth hormone $(\mathrm{GH})$ receptor polymorphism does not influence the effect of GH treatment (66 microg/kg per day) or the spontaneous growth in short non-GHdeficient small-for-gestational-age children: results from a two-year controlled prospective study in 170 Spanish patients. J Clin Endocrinol Metab 2006;91:3281-3286.

40 Carel JC, Chatelain P, Rochiccioli P, Chaussain JL: Improvement in adult height after growth hormone treatment in adolescents with short stature born small for gestational age: results of a randomized controlled study. J Clin Endocrinol Metab 2003;88:15871593.

41 Johnston LB, Dahlgren J, Leger J, Gelander L, Savage MO, Czernichow P, Wikland KA, Clark AJ: Association between insulin-like growth factor I (IGF-I) polymorphisms, circulating IGF-I, and pre- and postnatal growth in two European small for gestational age populations. J Clin Endocrinol Metab 2003;88:4805-4810.

42 Blum WF, Albertsson-Wikland K, Rosberg S, Ranke MB: Serum levels of insulin-like growth factor I (IGF-I) and IGF binding protein 3 reflect spontaneous growth hormone secretion. J Clin Endocrinol Metab 1993;76: 1610-1616.

43 Albertsson-Wikland K, Rosberg S: Reproducibility of 24-h growth hormone profiles in children. Acta Endocrinol (Copenh) 1992; 126:109-112. 